\title{
ELECTRONIC COMPLIANCE AND APPROVAL PROJECT (ECAP)
}

\author{
$\underline{\text { Annual Technical Progress Report }}$
}

Reporting Period Start Date: July 15, 2001

Reporting Period End Date: October 30, 2002

\section{Principal Authors:}

Hope Morgan, Information Resources Manager

Richard A. Varela, ECAP Project Manager

Deborah LaHood, ECAP Management Team Leader Susan Cisco, ECAP Legal/Records Management Team Leader

Mary Ann Benavides, ECAP Technical Team Leader

Donna Burks, ECAP Business Team Leader

Report Date: November 2002

DOE Award Number: DE-FG26-99BC15183

Submitting Organization:

Railroad Commission of Texas

P. O. Box 12967

Austin, TX 78711 


\section{Disclaimer}

This report was prepared as an account of work sponsored by an agency of the United States Government. Neither the United States Government nor any agency thereof, nor any of their employees, makes any warranty, express or implied, or assumes any legal liability or responsibility for the accuracy, completeness, or usefulness of any information, apparatus, product, or process disclosed, or represents that its use would not infringe privately owned rights. Reference herein to any specific commercial product, process, or service by trade name, trademark, manufacturer, or otherwise does not necessarily constitute or imply its endorsement, recommendation, or favoring by the United States Government or any agency thereof. The views and opinions of authors expressed herein do not necessarily state or reflect those of the United States Government or any agency thereof. 


\begin{abstract}
The Texas Railroad Commission (RRC), working in partnership with the United States Department of Energy and the oil and gas industry it regulates, is implementing a strategy for improving efficiency in regulations and significantly reducing administrative operating costs through the Electronic Compliance and Approval Process (ECAP). The project will streamline regulatory compliance and reporting by providing the ability to electronically submit, process, and query oil and gas applications and reports through the Internet-based ECAP system.

Implementation of an ECAP drilling permit pilot project began September 1999 after funding resources were secured - a $\$ 700,000$ grant from the U.S. Department of Energy and an appropriation of $\$ 1.4$ million from the Texas Legislature. The pilot project involves creating the ability to file, review, and approve a well's drilling permit application through a completely electronic process. The pilot project solution will ultimately provide the infrastructure, technology, and electronic modules to enable the filing of all compliance permits and performance reports through the internet from a desktop computer.
\end{abstract}

The pilot project was conducted in three phases. The first phase, implemented May 2000, provided the infrastructure that allows the electronic filing and approval of simple drilling permit applications, associated fees, and attachments. The official "roll-out" of ECAP and the first electronically filed drilling permit application occurred on May 11, 2000 in Dallas in conjunction with an Internet Workshop sponsored by the Petroleum Technology Transfer Council. After the completion of Phase I, the ECAP team conducted an extensive review of progress to date and analyzed requirements and opportunities for future steps. The technical team identified core infrastructure modifications that would facilitate and better support future development and expansion of the ECAP system and work began on database structure modifications.

The second phase of the pilot project was implemented in October 2002. Phase II was the complete rewrite of the ECAP core system and included internal workflow processing capabilities and the ability to process more complex new drill permits such as horizontal, directional, pooled acreage and non-concurrent production restrictions all with additional attachments and reports.

Phase III, completed in August 2003, concluded the ECAP pilot project. It allowed the processing of all types of drilling permits and completed the integration with existing geographic information systems, mainframe and electronic document management systems as well as the state payment portal.

This report contains detailed information documenting accomplishments and problems encountered during the ECAP pilot project and plans for future steps. 


\section{$\underline{\text { Table of Contents }}$}

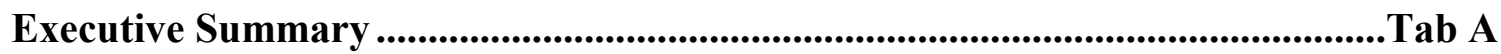

Experimental: Research; Materials; Equipment....................................................Tab B

Results and Discussion................................................................................................Tab C

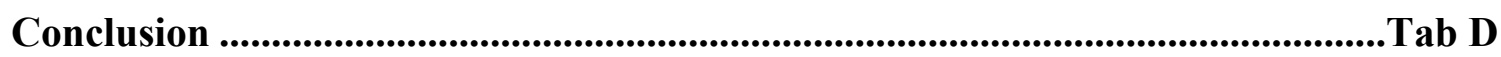

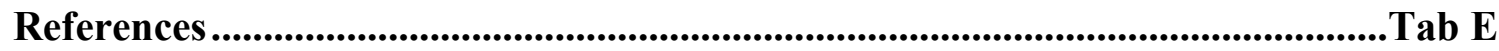

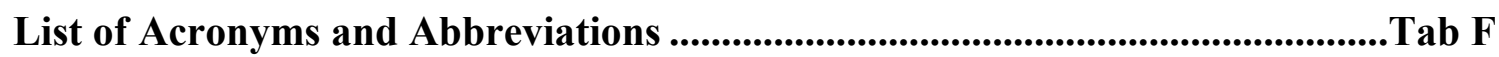

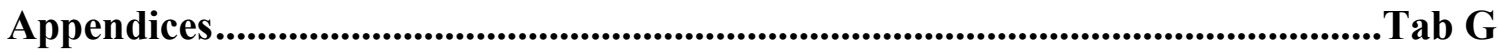

Appendix 1: Initial ECAP Project Plan

Appendix 2: ECAP Phase 1 Detail Project Plan

Appendix 3: ECAP Phase II Detail Project Plan

Appendix 4: ECAP Phase III Detail Project Plan

Appendix 5: ECAP Field Rules Query Screen

Appendix 6: ECAP GIS Information Screen

Appendix 7: ECAP Payment Screen

Appendix 8: Texas Online - State Payment Portal Screen 


\section{ELECTRONIC COMPLIANCE AND APPROVAL PROCESS}

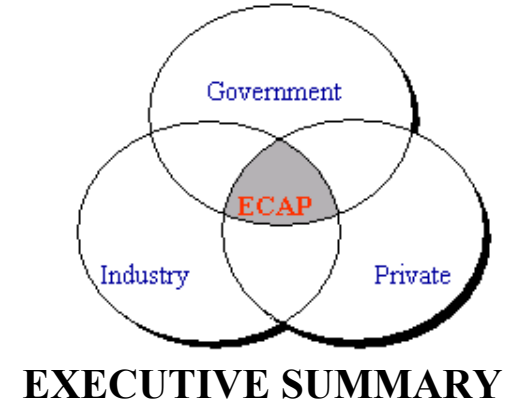

The Railroad Commission of Texas, in partnership with the United States Department of Energy and the oil and gas industry it regulates, is implementing a strategy for improving efficiency in regulations and significantly reducing administrative operating costs. The solution is called the Electronic Compliance and Approval Process (ECAP). The ECAP project is the first effort to move beyond EDI reporting of performance data to handle two-way electronic application and permitting. The pilot step for the project creates the ability to file, review, and approve a well's drilling permit application through a completely electronic process. The process encompasses all aspects of permit requirements including security, authentication, fee collection, and transmittal of attachments. Over time, the electronic infrastructure developed through this pilot will be expanded to include all processes in the full regulatory and compliance life cycle of wells, leases, and fields.

The Railroad Commission and the oil and gas industry need to operate more efficiently due to rising costs, lower staffing levels and increased budget restrictions. The ECAP project is a joint initiative that proposes a realistic solution for streamlining regulatory demands through the implementation of a totally paperless workflow between industry and government.

During 1997, Texas operators filed nearly 150,000 permit applications with the Railroad Commission. Fifteen thousand $(15,000)$ of these were drilling permit applications. It is estimated that a savings to industry of $\$ 200$ to $\$ 400$ per drilling permit can ultimately be achieved upon implementation of the ECAP pilot project. This represents a potential annual savings of \$3-6 million for industry.

Initial startup of the pilot project began in September 1999 after funding resources were secured - a $\$ 700,000$ grant from the U.S. Department of Energy and an appropriation of \$1.4 million from Texas Legislature. The costs of the three-phase drilling permit pilot step, which also provides the infrastructure and modules for future compliance processes, are estimated to be $\$ 1.4$ million. Once the ECAP project is expanded beyond the pilot step to incorporate all permit applications, the cost is estimated to be $\$ 3.1$ million with completion in 2005. However, the resulting savings to industry and the state will be substantial. Total annual industry savings in Texas, based upon only $25 \%$ utilization of electronic filing, is expected to be $\$ 17,500,000$. Higher utilization of the system will obviously yield correspondingly greater benefits.

Because Texas' drilling activity is the largest and most diverse of any state, Texas and the Railroad Commission are positioned to assume a leadership role in developing technology solutions that will ultimately serve as a model for a paperless regulatory environment. The ECAP project is a low risk solution that utilizes proven technology tools to implement electronic compliance processes. The result will be regulatory efficiency and substantial savings for the oil and gas industry, for Texas, and for other producing states. 


\section{EXPERIMENTAL Methods for Research; Materials and Equipment Used}

The continued need for the accessibility and availability of Railroad Commission data remains the goal across all areas of the agency. The ECAP project was first conceived when Railroad Commissioners and staff met with industry representatives to research ways to improve the regulatory process and make it more efficient through information management strategies. The ECAP project continues to rely upon the joint Industry/Railroad Commission staff work group for critical decisions that impact the project approach and timeline.

This third annual technical progress report coincides with the completion of the ECAP pilot project. Phase II of the Railroad Commission project employed new methods for the management and storage of information. Phase II plans were to rebuild the foundation of the ECAP project by implementing the four frameworks and applications outlined in the previous technical report. Phase III plans were the deployment of additional filing capabilities through the reuse of the frameworks built in Phase II. The completion of Phase II and Phase III is addressed in this report. During Phase III several new technology issues were also reviewed and their findings are presented in this report.

\section{Framework Implementation}

The implementation of Phase II introduced a higher level of technical complexity to the project than initially planned and additional time was needed to fully document the core operations of the framework. The frameworks, although reduced in number, put in place processing capabilities that were multi-faceted in order to support both internal and external requirements. All of the frameworks required additional testing to support the flexibility needed to enhance the approval process. This included automated checks for compliance with field rules, "locking" features in the workflow, the implementation of several additional standardized components for Phase III and the continued adherence to statewide accessibility standards for Internet-based applications.

With the resolution of the Phase II issues, the ECAP project continued to meet the goals of increased efficiencies for the permit filer and decreased turnaround time on the processing of drilling permits. The technical team has been diligent in its efforts to ensure best practices are followed for software construction and documentation and to ensure knowledge transfer to RRC staff is complete.

Phase III -New Business Requirements

The internal business review analysis for Phase III requirements identified some issues that were more complex than anticipated. In several instances the existing manual business process resulted from a workaround of the shortcomings of the automated legacy system. The ECAP team embarked on a thorough examination of the intent of the business process and implemented a streamlined business process that was fully supported in the new automated system. The efforts of this work eliminated the perpetuation of a less than optimal process and resulted in an 
automated system based on clear-cut and improved business procedures for handling and storing additional information and payments during the approval process.

New technical issues were identified and addressed through the integration of ECAP with data from the Commission's geographic information system (GIS) and electronic document management system. In both instances the integration issues were addressed through the development of standard browser interfaces. The GIS integration uses a java-based application developed for viewing map data from an Oracle database using ArcSDE.

The imaging system posed more technical problems since it stored documents internally by attaching a proprietary header record to the TIFF image records. The imaging system interface required the use of a vendor supplied automated routine for removing the header record and converting the TIFF image to a PDF. The ECAP system calls this routine and provides viewing of stored documents with any standard web browser.

Phase III of the ECAP project was implemented following the staggered deployment of new external application features initiated in Phase II. A detailed outline of the Phase III time line is provided below.

- March 20 - ECAP integration with GIS allowed operators to view the area surrounding their proposed well location including the neighboring well locations. This includes identifying information about surrounding wells such as operator name, API number, field, etc.

- April 12 - ECAP integration with Texas Online, the state payment portal, providing secured, automated, real-time processing of drilling permit fees. Currently the payment portal supports the processing of payments via MasterCard and Visa.

- April 12 - ECAP integration with EDMS to use the internal electronic management system, Visiflow, for the storage and retrieval of electronically stored documents.

- April 24 - ECAP system supports the filing of new drill permits applications with statewide rule exceptions. This includes SWR 37, 38 and 39 exceptions.

- April 30 - New drills complete. New drills represented 75.5 percent of all drilling permits filed in FY2002. Training on expanded ECAP capabilities was conducted through a series of half-day electronic information seminars given by staff across the state at no charge to attendees and during the Oil and Gas Forms and Procedures Seminars in April and June and the Regulatory Expo in Austin in October.

- June 17 - ECAP system supports the filings with recompletions, re-entries, field transfers and re-classes. Recompletions accounted for 19.7 percent; re-entries accounted for 3.5 percent; field transfers accounted for 1 percent; and re-classes accounted for .2 percent of all drilling permits filed in FY2002. 
- August 28 - ECAP pilot phase is completed with the ability to support amended and corrected filings. Of the total drilling permits filed in FY 2002, 15.2 percent had amendments submitted and .4 percent had corrections.

\section{Technology Tools Reviewed}

There were no new technology tools implemented during Phase III, however during this phase, the Commission began the implementation of the new Oil and Gas Migration project that would move the back-end legacy systems to the open systems environment. This change to back-end processes would greatly impact the project. The ECAP project was envisioned as a web interface that would allow data entry by industry directly into the Commission's backend of stable mainframe databases. This interfacing will provide speedier service and better access to this data for both the public and RRC staff. The Oil and Gas Migration (OGM) project will change the dynamics of ECAP as it is expanded beyond the pilot project by enabling the Commission to better plan for a comprehensive suite of internal and external improvements.

Both projects include data migration, database redesign and business process re-engineering. However, the primary focus of ECAP is to provide the front-end interface while the primary focus of the OGM is to completely re-engineer and redesign the Commission's business processes and databases as well as migrate the legacy data to an open systems environment. As a result, the ECAP and OGM projects are being merged. As we found in Phase I and Phase II of the ECAP project, basic database design is dependent on both the business rules and the interfaces. Beyond the pilot phase, for both projects to be successful we must balance the needs of the database design with the needs of the interface used both by the industry, public and our own internal staff.

Decisions made by the OGM project will ultimately impact ECAP. For example, a common thread in several of the OGM vendor proposals was the role of the Web Objects development tool in the migration effort. The Web Objects tool was selected over three years ago when it was one of the few premiere web development tools. With the technological assessment that will be conducted during Phase I of the OGM project, new web-development tools and techniques will be introduced.

A merging of the projects brings several positive elements to the process:

- Time Savings - the business process review and re-engineering can be performed once with the results implemented in both the database design and the interface. This saves both resources and time through joint process re-engineering, design and development sessions as well as one set of user testing components.

- Solution Consistency- it negates the possibility of each project team arriving at different solutions to the same issue that could possibly require additional database and interface rework or resources to arrive at a compromise solution. 


\section{RESULTS and DISCUSSION}

The final phase of the ECAP pilot project used new processing framework developed in phase II to gradually deploy filing capabilities needed for all types of drilling permits. This staggered deployment resulted in a constant increase in utilization throughout Phase III. The additional layer of information resulting from the geographical interface to ECAP appeared to be a major incentive for new filers. The visual representation of existing well locations on a map proved to be a signifcant aid to users of the ECAP system. In addition, the ability to file all new drills eliminated a great deal of uncertainty regarding the types of drilling permit applications that could be filed in the system. As more complex filings that addressed exceptional issues became available through ECAP, still another set of filers began using the system. Another factor that greatly added to system utilization levels was the outreach and training provided by Commission staff. All of these conferences and educational events were well attended and resulted in an immediate increase in system usage that persisted inspite of a temporary decline in drilling permit activity.

\section{Current System Utilization Statistics}

As of October 2002, the ECAP system has processed and approved over 1,200 drilling permit applications. To date, there have been 169 companies and consultants with agreements on file, allowing them to intiate the permit process at any point in time. Although there have only been 103 companies actually using the system, this represents almost a 200 percent increase in system users from one year ago. This increase is the result of the new features added to the system and it is expected that the number of users will grow as companies become aware of the added capabilities. A monthly breakdown of ECAP filings statistics as of October 2002 is shown below. The "Total Possible" column shows all permit applications filed that met the criteria for the drilling permit type currently available through ECAP. These figures show that starting in August there were significant increases in system usage. With the full functionality introduced in August, ECAP filings increased from 9.9 percent of total monthly filings to 17 percent of total filings in October.

\begin{tabular}{l|c|r|r|r|r|}
\hline \multicolumn{1}{c|}{ Month } & Year & ECAP W-1s & Possible W-1s & $\begin{array}{c}\text { Adjusted Possible } \\
\text { Filings* }\end{array}$ & $\begin{array}{c}\text { \% Of Possible } \\
\text { filings }\end{array}$ \\
\hline May & 2000 & 1 & 430 & 396 & \\
June & 2000 & 2 & 440 & 396 & $3.51 \%$ \\
July & 2000 & 13 & 440 & 476 & $5.88 \%$ \\
August & 2000 & 28 & 529 & 469 & $4.27 \%$ \\
September & 2000 & 20 & 521 & 457 & $5.03 \%$ \\
October & 2000 & 23 & 508 & 394 & $4.57 \%$ \\
November & 2000 & 18 & 438 & 410 & $5.13 \%$ \\
December & 2000 & 21 & 455 & & \\
\hline & & & & 474 & $4.01 \%$ \\
January & 2001 & 19 & 527 & 458 & $4.15 \%$ \\
February & 2001 & 19 & 509 & &
\end{tabular}




\begin{tabular}{|c|c|c|c|c|c|}
\hline Month & Year & ECAP W-1s & Possible W-1s & $\begin{array}{c}\text { Adjusted Possible } \\
\text { Filings* }\end{array}$ & $\begin{array}{c}\% \text { Of Possible } \\
\text { filings }\end{array}$ \\
\hline March & 2001 & 28 & 578 & 520 & $5.38 \%$ \\
\hline April & 2001 & 34 & 485 & 437 & $7.79 \%$ \\
\hline May & 2001 & 27 & 596 & 536 & $5.03 \%$ \\
\hline June & 2001 & 24 & 655 & 590 & $4.07 \%$ \\
\hline July & 2001 & 22 & 537 & 483 & $4.55 \%$ \\
\hline August & 2001 & 22 & 575 & 518 & $4.25 \%$ \\
\hline September & 2001 & 19 & 315 & 284 & $6.70 \%$ \\
\hline October & 2001 & 19 & 551 & 496 & $3.83 \%$ \\
\hline November & 2001 & 34 & 499 & & $6.81 \%$ \\
\hline December & 2001 & 28 & 473 & & $5.92 \%$ \\
\hline January & 2002 & 37 & 454 & & $8.15 \%$ \\
\hline February & 2002 & 36 & 429 & & $8.39 \%$ \\
\hline March & 2002 & 36 & 405 & & $8.89 \%$ \\
\hline April & 2002 & 45 & 548 & & $8.21 \%$ \\
\hline May & 2002 & 67 & 723 & & $9.27 \%$ \\
\hline June & 2002 & 66 & 666 & & $9.91 \%$ \\
\hline July & 2002 & 87 & 884 & & $9.84 \%$ \\
\hline August & 2002 & 108 & 889 & & $12.15 \%$ \\
\hline September & 2002 & 149 & 834 & & $17.87 \%$ \\
\hline October & 2002 & 163 & 913 & & $17.85 \%$ \\
\hline Total & & 1,215 & 16,806 & 7,793 & $7.23 \%$ \\
\hline
\end{tabular}

Prior to October 15, 2001 the Possible Filings was adjusted to 90\% of the total. This was to account for the Pooled and Non-concurrent production filings. As of 10/15/2001 these types were accepted therefore the adjustment was discontinued. 


\section{How do we compare to other regulatory processes implemented over the Internet?}

To date, the majority of oil and gas reglatory efforts utilzing the Internet have been primarily informational. In our review of Internet-based regulatory efforts as of July 2002, only three entities, including Texas, have implemented online permitting and reporting. The other two entities are the states of Pennsylvania, and the Bureau of Land Management (BLM). All of these entities have implemented an interactive process that incorporate a redesign and reengineering of the business processes. The BLM has implemented a well information system that allows eligible operators to submit permit applications over the internet for wells on federal lands. Pennslyvania has implemented on line filing but currently serves a very limited population of operators. Other states, like New Mexico, West Virginia and Ohio, have provided electronic reporting capabilities using proprietary networks or e-mail but have not utilized the Internet as the interface for processing data from regulated entities. Most states have utilized the Internet to provide public access to data. Providing access to historical trend information and documents is vital to promoting research and exploration of energy resources and it can be accomplished with minimal complexity and security concerns.

Louisiana is one example of a state that has developed an extensive online Internet-based energy information system. The Louisiana SONRIS system provides quick and easy access to frequently requested information inlcuding geographic map and historical document information. The Oklahoma Corporation Commission has also developed a system that provides easy browse capabiltiy of Well, Operator, UIC information. The state of Kansas has also implemented a system for online viewing of reservoir characteristics.

The results of the review of energy producing states indicated the majority of the 19 energy producing states included internet-based permitting processes as part of their five-year plans. Currently, in many states the Internet is used to distribute electronic copies of forms that can be used to file information with the regulatory entities.

The architecture used for Internet-based systems varies from state to state. An example being followed by many of the states is the Risk Based DMS systems being developed for California. The implementation of this system was delayed as a result of technology enhancements; the new RBDMS will use the .net platform instead of the initially planned active server pages platform. Louisiana's implementation will be based on its current system architecture, which uses Oracle forms and database products.

The Texas ECAP project is currently using Apple's Web Objects software development tools and Oracle database, which although proprietary in some aspects, allows for full standard Java connectivity. Future expansions of ECAP will be based on a standard implementation of the J2EE technology and continue with the reuse of applicable frameworks design developed during the pilot project. 
The state of Texas has implemented a web site for the sharing of programming code between governmental entities. The purpose of the site is to maximize the utility of the state's investment in technology by facilitating the sharing of technology solutions. The site used to inform others of these solutions is called GovernmentDomain.com. This site outlines technology solutions developed by governmental entities that can be reworked rather than re-invented. The ECAP project will provide access to its code, framework design, database structure and documentation through this site. This will maximize the ability of other energy producing states to leverage the ECAP investment. 


\section{CONCLUSION}

The ECAP pilot project is providing the Commission and other entities with a roadmap to follow from both a procedural and technological standpoint. The project is utilizing best practices in implementing electronic government processes with benefits to both the regulated entities and government.

The pilot project has incorporated business process redesign throughout the development phase. Moving the internal and external processes from paper to online was more than putting a form design on the Internet. In fact, without reengineered business processes, the submission of data on web-enabled templates that mirror the paper form may actually inhibit the current internal business process. ECAP initiated system modifications resulted in processing changes that also streamlined the paper process. Additional benefits include providing the public with real-time access to drilling permits approved through ECAP. The future internal challenge will be utilizing the ECAP system to process drilling permits that are filed through the paper process.

The continued communications with stakeholder groups and educational outreach sessions have really helped to promote ECAP use. The timesavings to the business unit have proven themselves through continued increases in system utilization in spite of changes in the economic climate. The implementation of solutions to the issues identified by the regulated community group has proven to be one of the core reasons utilization continues to increase.

ECAP was developed with understanding that the customer business process is essential in designing and building a system that is truly Government to Citizen ( $\mathrm{G}$ to $\mathrm{C}$ ). The analysis included an in-depth review of the current process from both the regulatory and customer perspective and identified several reengineering and redesign opportunities. These opportunities included:

1. Eliminating certain data requested from the customer due to changes in the regulatory process.

2. Making historical data that was difficult to access, available on line.

3. Eliminating the need for the customer to re-submit the same information more than once.

4. Implementing an on-line process that mapped to industry's business process during the submittal of a drilling permit application.

Structured design and standards simplify the transition to newer technologies. The framework approach implemented by the ECAP team followed an object-oriented design simplifying the integration with other functions in the open systems environment. This approach will also facilitate the conversion of certain processes developed to newer technologies when required.

The geographic information system (GIS) interface provided through ECAP supports the common belief that visual aids contribute to a better understanding of a process. The easy access to maps over the Internet complements the filing process and encourages system usage. With the 
integration of the Commission's GIS, the locations of existing wells, water and roads are readily available. GIS data provides the ECAP filer with additional information about the application permit area. This adds to the filers' ability to proactively identify potential filing irregularities before the submittal of the drilling permit application.

Finally, the framework construction approach resulted in consistent on-time delivery of new functionality. This clearly illustrates the benefits of standards-based design and technology. The ability to reuse components significantly shortened the development timeframe for new permit types. This same approach simplified the integration with the state payment portal as well as the back-end legacy systems. These techniques will be leveraged with the ongoing migration of all of the legacy systems to the new open systems environment and will strengthen further enhancements and improvements in the overall regulatory framework. 


\section{REFERENCES}

Texas Railroad Commission Oil and Gas \& Information Technology Services Divisions (1998) Report on Information Management Issues. Report to the Railroad Commission and the Texas Oil and Gas Association. Unpublished.

Texas Railroad Commission Oil and Gas \& Information Technology Services Divisions, (1998) ECAP Project. Report and Grant Solicitation to the United States Department of Energy. Unpublished.

Cisco, S. \& LaHood, D., (2000) "Texas Railroad Commission Introduces Internet-based Process", Oil \& Gas Journal, May 8, 42-46.

Texas Railroad Commission Information Technology Services Division, (2000) ECAP Technical Frameworks and Guidelines. Report to the ECAP Management Team. Unpublished.

Texas Railroad Commission Oil and Gas \& Information Technology Services Divisions (2000) The Electronic Compliance and Approval Project. Report for NASIRE Award Nomination. Unpublished.

Morgan, H. \& Cisco, S. (2000) Internet-Based Forms Processing. Presentation to Western State Land Commission Association. Unpublished.

Steven Cohen \& William Eimicke (February 2001) The Use of the Internet in Government Service Delivery. The PricewaterhouseCoopers Endowment for The Business of Government, E-Government Series.

United States Government Accounting Office Report to Congressional Requesters (February 2001) Regulatory Management, Communication About Technology-Based Innovations Can Be Improved, GAO-01-232.

Diane Kittower (2000) "The IT Touch, Technology experts cite 12 projects that help manage government services more efficiently." Governing magazine, October 2000. 


\begin{tabular}{|c|c|c|c|}
\hline \multicolumn{4}{|c|}{ ACRONYMS \& ABBREVIATIONS } \\
\hline $\begin{array}{l}\text { Mainframe } \\
\text { CPU }\end{array}$ & IBM Multiprise 2003 - 116 & Oracle & $\begin{array}{l}\text { Relational Database (RDBMS) used } \\
\text { at the Commission }\end{array}$ \\
\hline $\begin{array}{l}\text { Legacy } \\
\text { Objects }\end{array}$ & $\begin{array}{l}\text { Mainframe Screen Scraping } \\
\text { Software }\end{array}$ & TIFF & Tagged Image File Format \\
\hline $\begin{array}{l}\text { Web } \\
\text { Objects }\end{array}$ & $\begin{array}{l}\text { Web-based applications } \\
\text { development tool }\end{array}$ & TCP/IP & $\begin{array}{l}\text { Transmission Control } \\
\text { Protocol/Internet Protocol }\end{array}$ \\
\hline $\begin{array}{l}\text { E- } \\
\text { Commerce }\end{array}$ & $\begin{array}{l}\text { Conducting business transactions } \\
\text { over the internet }\end{array}$ & RRC & Railroad Commission of Texas \\
\hline ArcInfo & $\begin{array}{l}\text { ESRI GIS data management and } \\
\text { analysis software }\end{array}$ & UNIX & An Open Systems Operating System \\
\hline ArcSDE & $\begin{array}{l}\text { ESRI Spatial Data Engine GIS } \\
\text { Software }\end{array}$ & MEFA & Master Electronic Filing Agreement \\
\hline DBA & Data Base Administration & MCFA & Master Consultant Filing Agreement \\
\hline DEC Alpha & $\begin{array}{l}\text { Digital Equipment Corporation } \\
\text { Midrange Processor }\end{array}$ & & \\
\hline ECAP & $\begin{array}{l}\text { Electronic Compliance and } \\
\text { Approval Process }\end{array}$ & RDBMS & $\begin{array}{l}\text { Relational Data Base Management } \\
\text { System }\end{array}$ \\
\hline ESRI & $\begin{array}{l}\text { Environmental Systems Research } \\
\text { Institute }\end{array}$ & SAD & Security Administrator Designation \\
\hline EDMS & \begin{tabular}{|l|} 
Electronic Document \\
Management System
\end{tabular} & Solaris & $\begin{array}{l}\text { Version of the UNIX Operating } \\
\text { System Running on the Sun } \\
\text { Microsystems Computers }\end{array}$ \\
\hline J2EE & $\begin{array}{l}\text { Java } 2 \text { Platform, Enterprise } \\
\text { Edition }\end{array}$ & SONRIS & $\begin{array}{l}\text { Strategic Online Natural Resources } \\
\text { Information System }\end{array}$ \\
\hline GIS & Geographic Information Systems & NASIRE & $\begin{array}{l}\text { National Association of State } \\
\text { Information Resource Executives }\end{array}$ \\
\hline IP & Internet Protocol & OGM & Oil and Gas Migration Project \\
\hline IMS & $\begin{array}{l}\text { Information Management System } \\
\text { - Mainframe Database } \\
\end{array}$ & UIC & Underground Injection Control \\
\hline
\end{tabular}


Appendices 
Appendix 1: Initial ECAP Project Plan

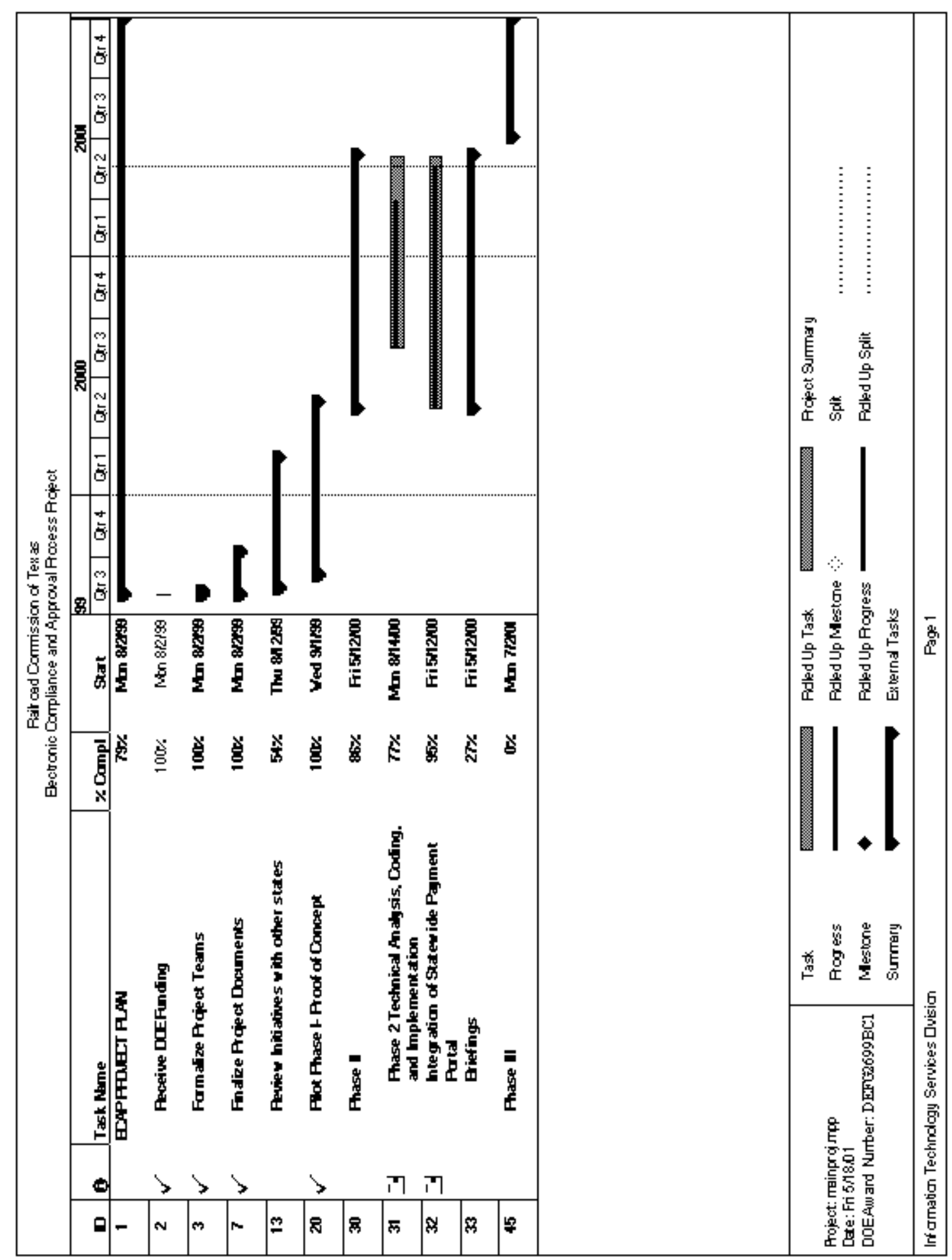




\section{Appendix 2: ECAP Phase I Detail Project Plan}

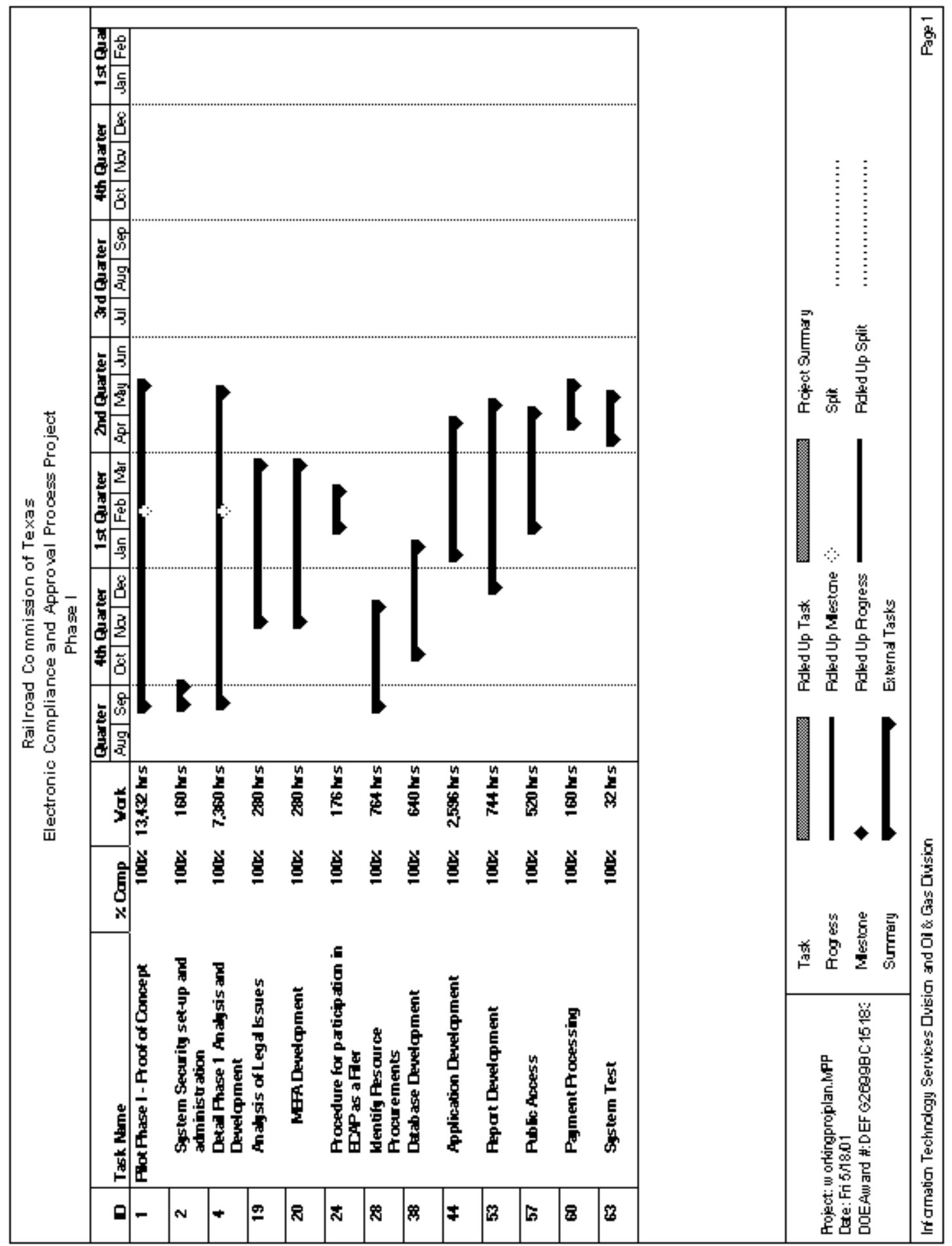


Appendix 3: ECAP Phase II Detail Project Plan

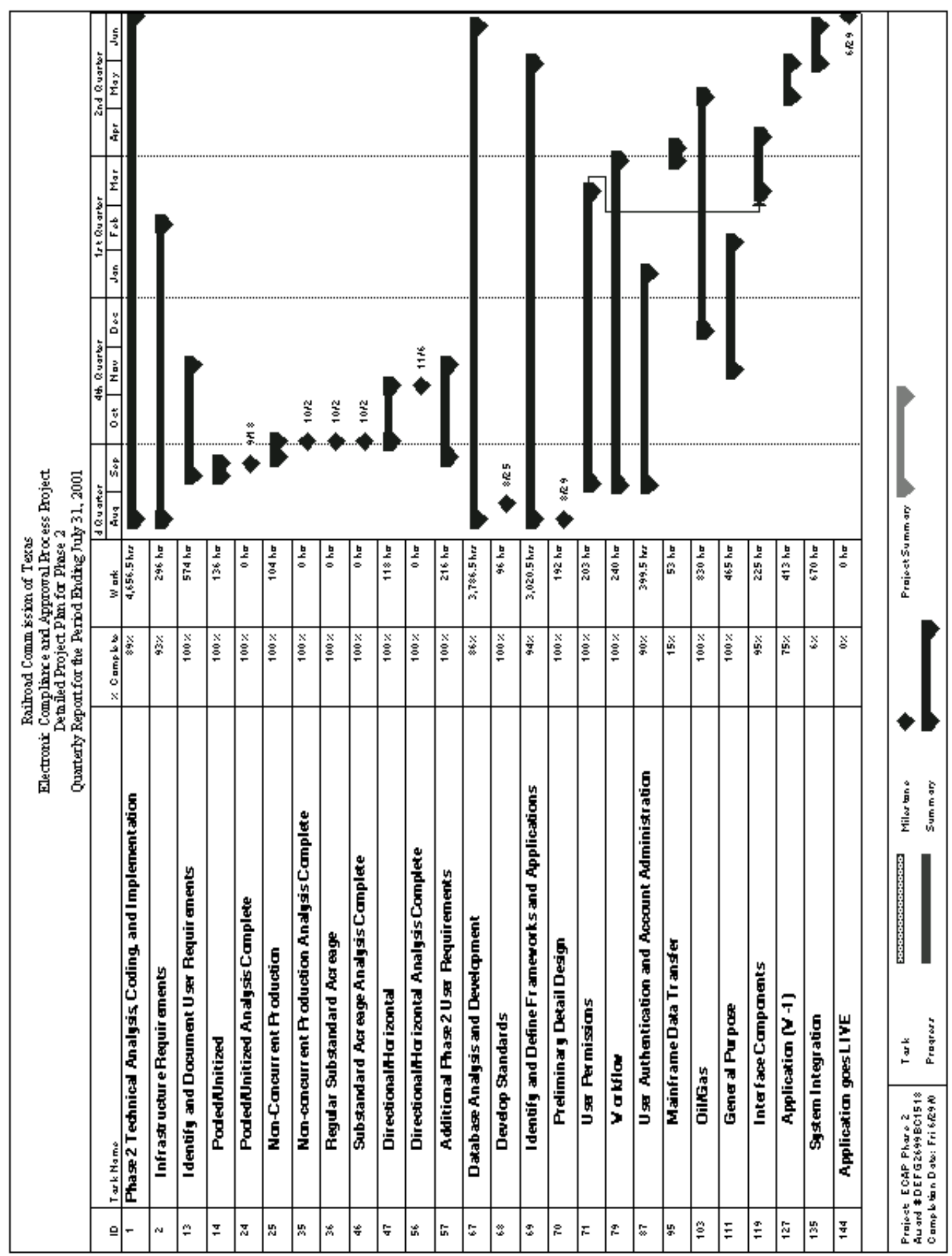


Appendix 4: ECAP Phase III Detail Project Plan

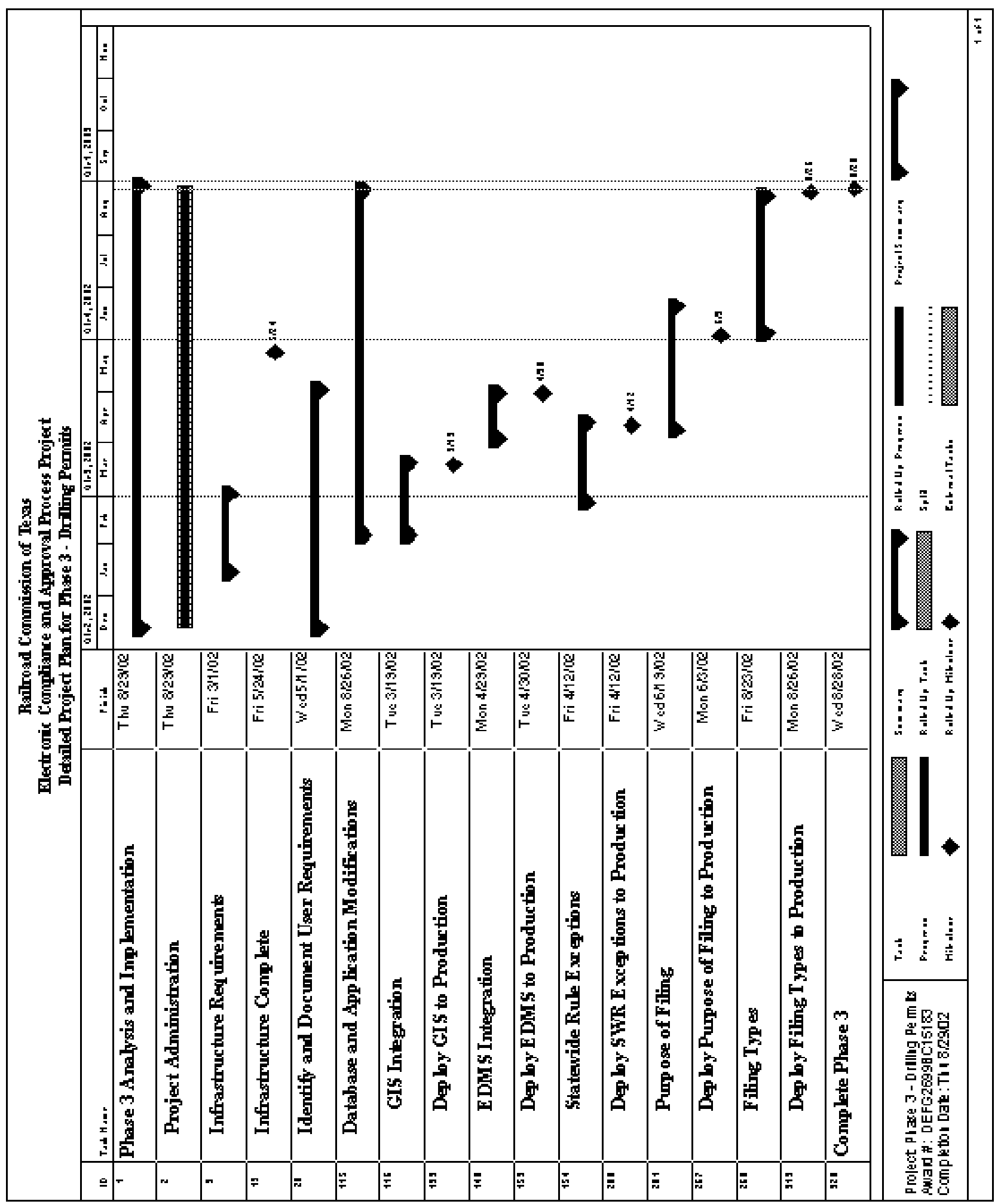




\title{
Appendix 5: ECAP Field Rules Query Screen
}

\author{
FIELD RULES QUERY \\ THIS SCREEN REFLECTS THE RESULT OF A QUERY FOR CURRENT RULES GOVERNING \\ THE SPACING AND DENSITY REQUIRED FOR THIS SPECIFIC FIELD AND RESERVOIR.
}

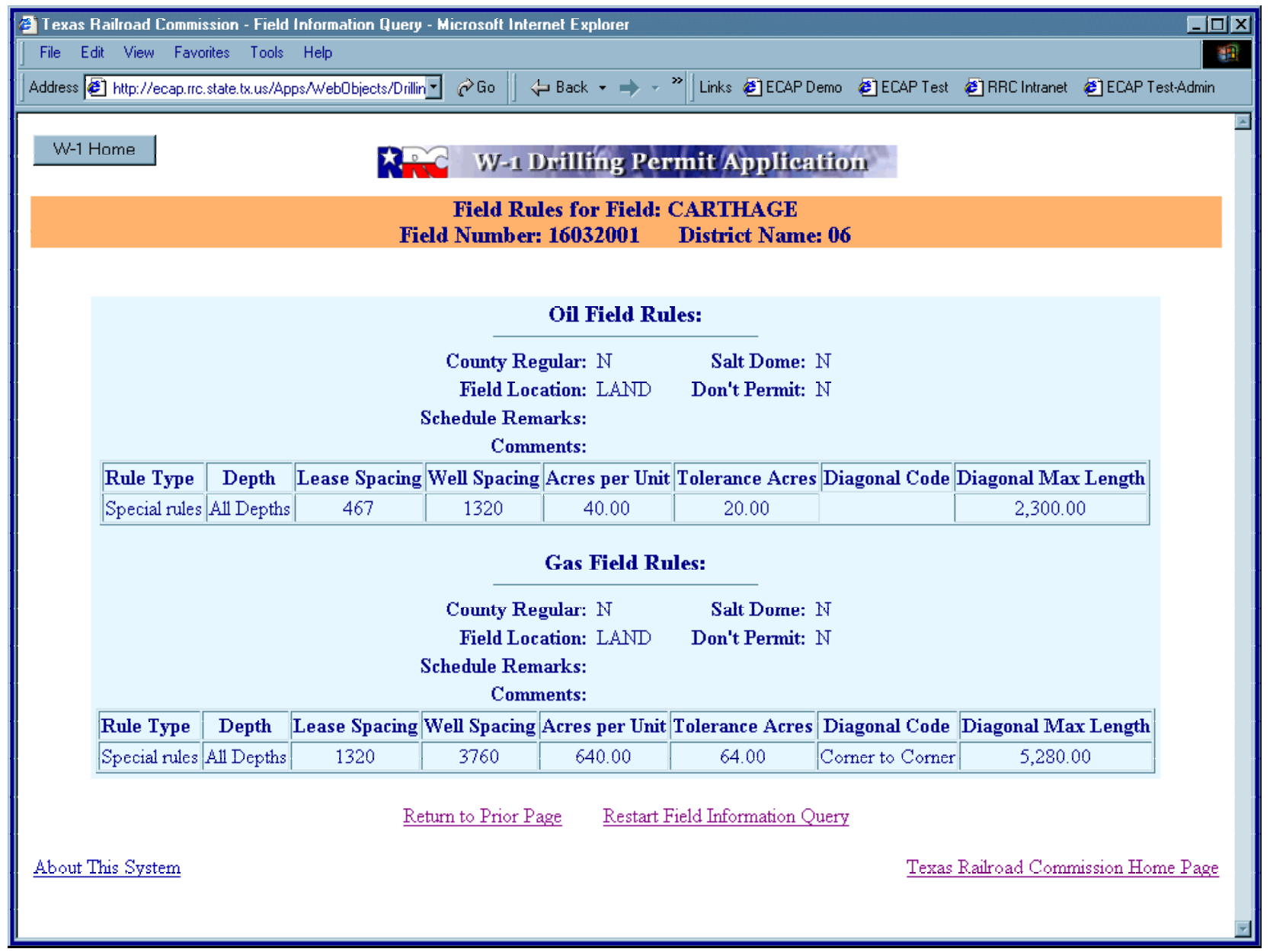




\section{Appendix 6: ECAP GIS Information Screen}

\section{GIS INFORMATION}

This picture shows wells in abstract 21 in Fayette county, Texas. Each colored spot depicts a well. The different colors reflect specific well types. The lines running from the well spot to the open polygon reflect a horizontal drill hole with the colored spot being the bottom hole, the polygon reflecting the surface location, and the line depicting the actual drainhole.

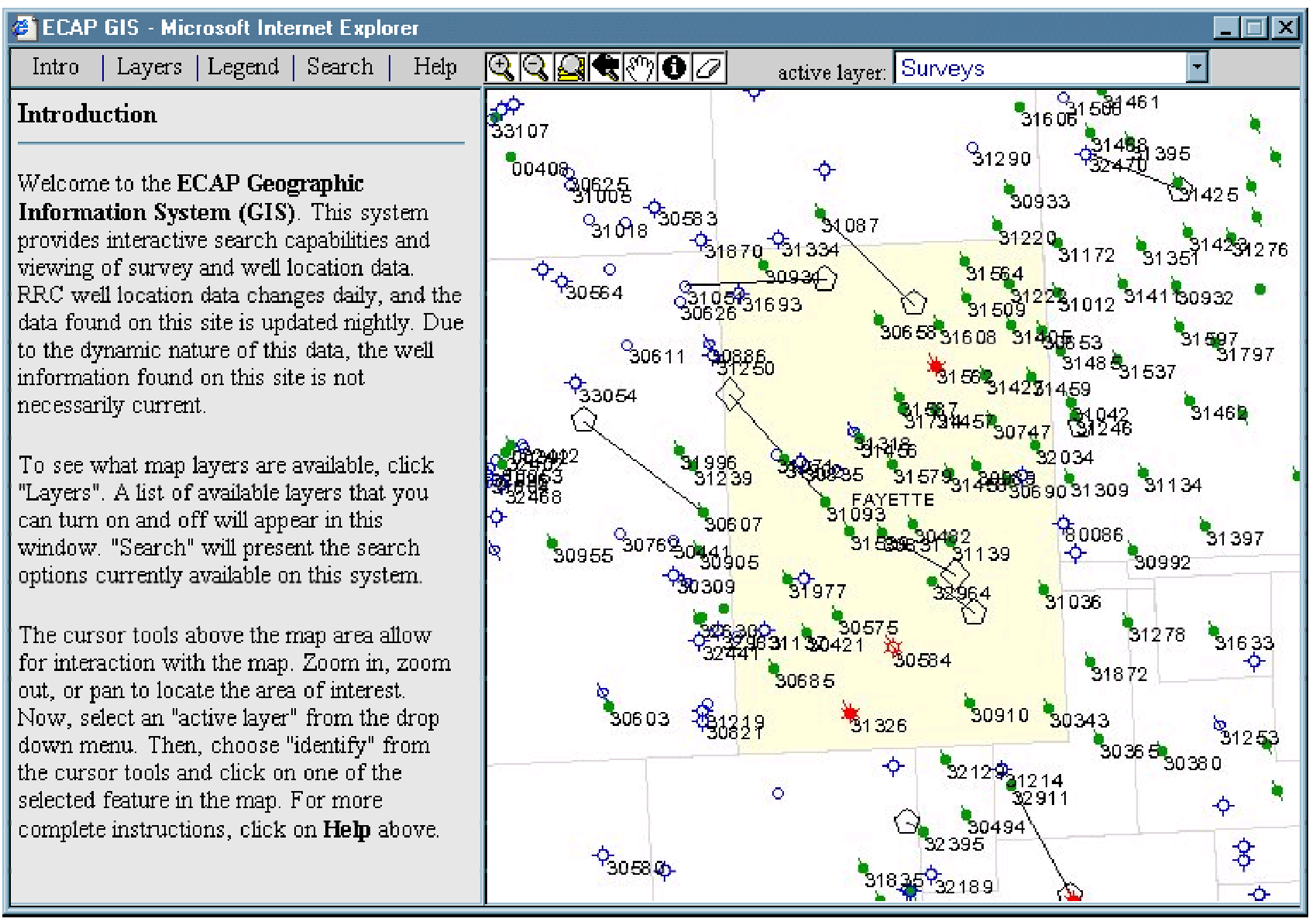




\section{Appendix 7: ECAP Payment Screen}

\section{Payment Portal}

The next two screens reflect the ECAP connection to the State of Texas' payment portal.

This screen advises the filer of certain browser requirements and details the actual cost of the permit application.

\begin{tabular}{|c|c|c|c|}
\hline \multicolumn{4}{|c|}{ Texas Railroad Commission - W-1 Drilling Permits System - Portal Page - Microsoft Internet Explorer } \\
\hline \multicolumn{4}{|c|}{ File Edit View Favorites Tools Help } \\
\hline 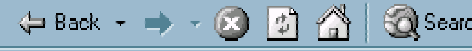 & hH History & * Favorites & \\
\hline $\begin{array}{l}\text { Op \#000001 - RAILROAD COMMISSION } \\
\text { DISTRICT 01 } \\
\text { Created 08/28/02 09:59:22 AM }\end{array}$ & ANDREWS - Rec & $\begin{array}{l}\text { PAN AM - Well \# } 11 \\
\text { ompletion (AMENDED) - Pending Approval }\end{array}$ & $\begin{array}{r}\text { Status \#522830 } \\
\text { API \# 003-38969 } \\
\text { Expires: 08/20/2004 }\end{array}$ \\
\hline
\end{tabular}

Total Payment Amount: 302.00

\begin{tabular}{|l|l|}
$\$ 300$ & This is a basic fee for a W-1 application to drill a well at a depth greater than $9000^{\prime}$. \\
$\$ 2$ & Payment Portal convenience fee. \\
\hline
\end{tabular}

Make Payment

NOTICE:

You need an Internet Browser that supports 128-bit security in order to enter this area of the site without errors. The State Payment Portal requires this high level of security to help protect your personal and financial information. The earliest browser versions from Microsoft and Netscape that support this level of security are:

\section{Microsoft Internet Explorer version 4.0 or greater \\ Or \\ Netscape Navigator version 4.0 or greater.}

To determine the version of Microsoft or Netscape browser that you have, click on the Help tab on the tool bar at the top of your browser page and select either: "About Internet Explorer" or "About Communicator." If you wish to upgrade your browser to a version that supports 128-bit security, you may also wisit either of these websites to download the current version of the browser you wish to use: Www.netscape.com Or www microsoft.com

To ensure a completed transaction please wait for verification of payment processing before proceeding.

Pressing the Make Payment button will transfer you to the State Payment Portal secure site for processing your payment. Upon completion of the transaction you will receive a return page with a trace number and authorization information. 


\section{Appendix 8: Texas Online - State Payment Portal Screen}

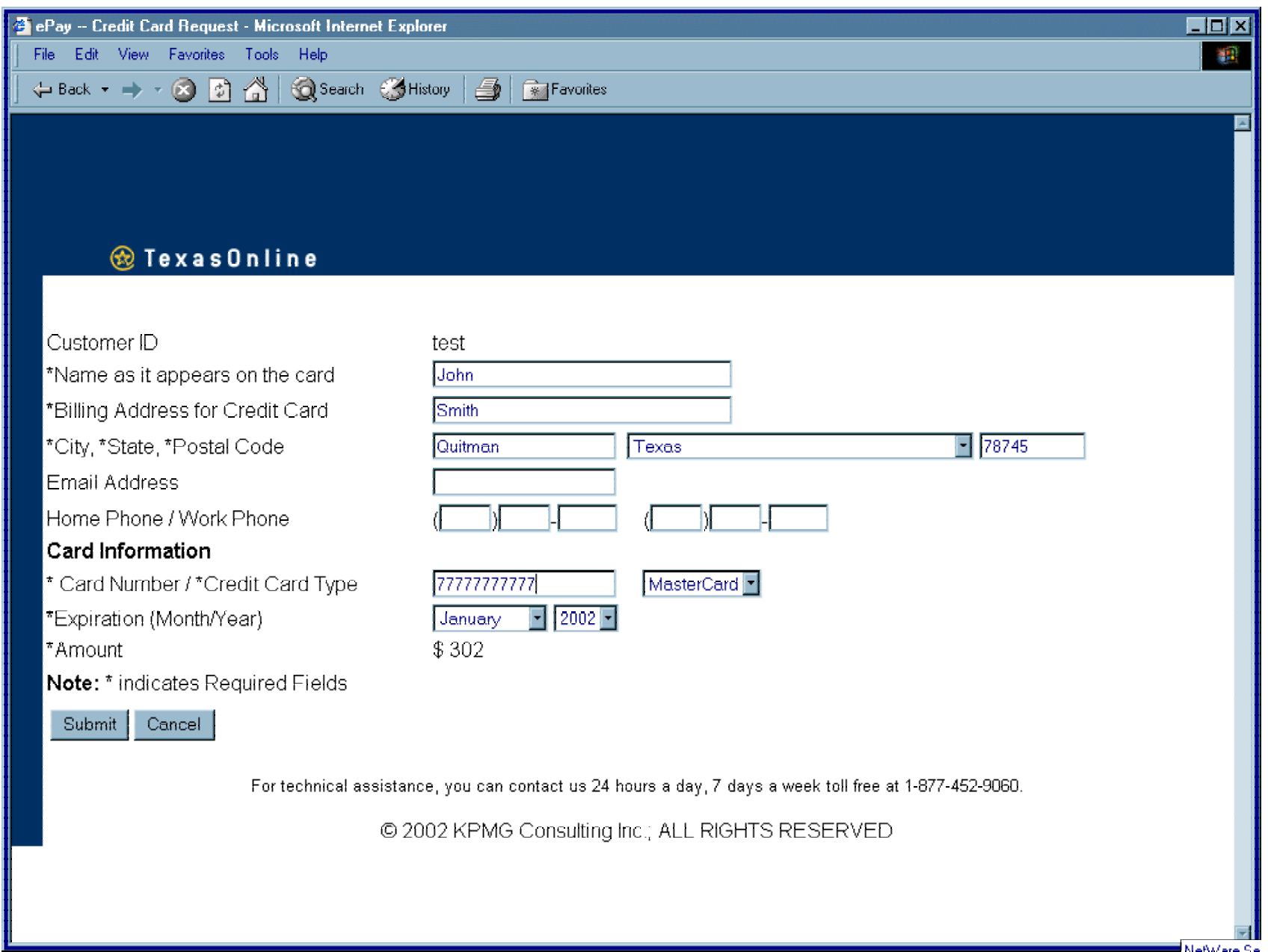

